\title{
The Struggle for Confiscation: An Imperialistic Look at Alfred Lord Tennyson's Poem "Ulysses"
}

\author{
Navid Salehi Babamiri ${ }^{1}$ \\ ${ }^{1}$ Department of English Language and Literature, Payame Noor University, Islamic Republic of Iran \\ Correspondence: Navid Salehi Babamiri, Department of English Language and Literature, Payame Noor \\ University, Islamic Republic of Iran. E-mail: navid_salehi1988@yahoo.com
}

Received: December 10, 2016 Accepted: January 2, 2017 Online Published: January 20, 2017

doi:10.5539/ells.v7n1p9 URL: http://dx.doi.org/10.5539/ells.v7n1p9

\begin{abstract}
The power of imperialism ascended during the Victorian age, when both the sense of nationalism and industrial revolution concurrently took place. Imperialism in its kind is the sense of domination of one group of people over another, or to a great point, it's the domination of one country on other countries to confiscate their properties and belongings. Here in the poem written by Alfred Lord Tennyson, the poet tries to ironize the situation by showing and focusing on such an old king (may be the king of England), who has recently come back home from his travels and has complained about his "idleness." This "idleness" for the king is equal to ceasing the kind of power, namely, if he does not move and battle, he has nothing for his country, and even he does not record a name for himself in the history of England. Thus the aim of the present paper is not only limitedto the relation between power and the sense of imperialism, a relation that leads to malicious and destructive behavior but it also condemns that kind of relation. However, it is done implicitly, as once the poet did in his poem, by showing the negative use of power in hands of some, like the king of England, who has done his best even at his death's door to continue again and conquer wherever he sees that brings benefits to him. Not surprisingly; the poem also implies to the battle of Troy in the sense of imperial actions.
\end{abstract}

Keywords: technology, power, confiscation, sense of imperialism

\section{Introduction}

According to John Morrissey, imperialism can be defined, "as a system of power, political economic ascendancy and cultural subordination, envisioned from the center of expanding nation-states and differentially operationalized in colonized spaces throughout the world" (Grek-Martin, 2015, p. 17). On the contrary, Hobson (2009) defines the term "imperialism", "[as a political tool] used either to proclaim or to denounce imperial rule, communicates poorly both temporally and spatially" (p. 16). However this term is to be defined historically. In Britain the traditional connotations of imperialism emerged in the 1860s and were defined for example by Whig-liberal C. W. Dilke in 1868, as a form of despotic government. From the British point of view,"the closest and the most obvious example of despotic rule was to be found in France where supporters of the Emperor Napoleon III were named 'Imperialists"' (p. 19).

But by a great consideration to the subject matter, it is said that imperialism started during the sixteenth century in England, however, during the span of Queen Victoria, it speeded over because the government wanted to explore lots of unknown places called "New World." This attempt for searching the unknown zones also owed to technological science and inventions that mostly happened during this age. Furthermore, it was during the first part of the nineteen's century that the sense of the "Second Industrial Revolution" between the years of 1870 to 1914, or even more elevated the sense of change in science and technology which in its turn culminated in the development of the railroad, iron ships, printing presses and electrical power generation. These progresses in these areas made the governments seek expansions in places which benefit the colonizer. On the whole, during this period, the vast area of Africa, Asia and the Middle East were under the control of colonial power. Britain confiscated, usurped and controlled a lot of colonies which according to Sokhanvar's citation in his book, "An Abridged Edition of The Norton Anthology of English literature (2008)," "the sun never sets on the British Empire" (p. 754), which describes Britain's power in holding the vastness of the areas.

However, as a matter of fact, England didn't waste its time. According to McDowall, England invested its power on both world traffic and world market. It didn't colonize everywhere which had no interest to it. But there were 
other areas, usually close to its own possessions or on important trade routes, which it wished everyone else to leave alone. It was as a result of defending these interests that Britain took over more and more land (1989, p. 131). Moreover, not far from this subject matter the "cultural materialism" does come outthat according to Tyson, "[it is] the direct result of economic domination, consists of "take over" of one culture by another: values of economically dominant culture increasingly replace those of the economically vulnerable culture until the latter appears to be a kind of imitation of the former" (2006, p. 425). So according to Hobson (2009):

"the British technical and administrative superiority [recognition on which area is to be best forconfiscation and seizing the properties], efficiency, inventiveness and independence are considered to be typical Victorian values, this conviction is said to be the paramount element in British Imperialism, a belief that England is the chosen nation, not by accident but because she deserves to be." (p. 23).

Finally, the present paper in regards to the sense of power both politically and scientifically is concerned with imperialism, an analysis which is understood from Tennyson's poem "Ulysses." Imperialism looks for ways in which the power of domination in one group or country rests on other poor ones. It is articulated not explicitly but implicitly in Tennyson's poem that as a king of England with a lot of power in hand he should not stop in his life but extend his domain. Thus the researcher attempts to show in this paper, according to the poem, how this sense of imperialism has made the king move forward to achieve expansion and to bring benefits for the honor of his country.

\section{Discussion}

Alfred Tennyson was born in Somersby, Lincolnshire. He was the fourth of a large family of children and as a clever boy from his childhood; he was mostly educated by his father. At age 8 he was capable enough to start writing poetry, but his time was not so up beating for him since he was plagued by the family's poverty and alcoholism; one brother had quarrel with his fatherall his time, another had to be sent to the insane asylum for life, another was a victim of opium completely. Because Alfred was completely shy and reserved, he was forgone attending school but instead his father, as a tutor, taught him the materials. He also, like Milton, devoted himself to his art and different branches of knowledge including sciences and as he ran in to the problems, he didn't spare to ask any questions he had in his mind from his father. After having been taught by his father, he did his best to go up in Trinity College and to his delight he could. It was here that he could publish his first volume of his poems and he was allowed to enter agroup of gifted poets known as "Apostles" who forced him to dedicate all his life to poetry.

During the span of his life Tennyson wrote a lot of poems, which according to Fletcher (1971), "most of them, like Keats the poet, deal with the appreciation for sensuous beauty and shades of feeling and elusive aspiration with marvelously the subtlepower" (p. 153) but unfortunately he suffered completely from the hostile criticism, which wounded his spirit and because he was a great fan of the Romantics, his poems sometimes bombarded with the brutal reviews. This indecent job from the side of reviewers made him secluded from the people or even be prevented from publishing any more poems for decades. Following this bitter event, another stroke came which was the death of his close friend Arthur Hallam, who was the leader of Apostles. This devastating psychological problem, however, inspired him to exorcise his grief In Memoriam; an elegy to his beloved friend, which also incorporates his doubt and at the same time his investigation toward the subjects of religious faith and the implications of evolutionary theory.

In 1833 Tennyson wrote his poem Ulysses which was not published until 1842. In this poem, as in other ones, Tennyson tries to deal with the national affairs. Tennyson's Ulysses is an exuberant person who has his speech with his wife, Penelope, and his son, Telemachus after he has recently arrived home. He wants to speak about the administrative responsibilities that he has toward his kingdom. He tells them about the time that he had acted as a voyager because he had to explore a lot of new places, but now that he has returned home, he feels depressed and restless. But now again he has itchy feet to come back to the road as he says, "I cannot rest from travel" (Tennyson, 2004, p. 426). Although before he had to confront lots of adversities, he now prefers that one to those ones since his domain has no glory to him but to "sleep" and "feed". He believes that life itself has no novelty and if he stays and doesn't explore other places he can neither broaden his attitude nor bring fame and honor to himself to show who he is in the country he governs. So as he says, "I will drink life to the lees" (Tennyson, 2004 , p. 426), he wants to use every minute of his life to come back to sea and once more time experiences exploring other countries and implicitly confiscate their lands and their properties. Additionally, when he defines his trip and travels, he enjoys every step of his life because once, as he remembers, he was both a sailor and a wanderer who roamed on earth with his "peers" and "drunk delight of battle" (Tennyson, 2004, p. 426), and also it made him know all the people and their manners, "Much have I seen and known-cities of men..." (Tennyson, 
2004, p. 426). Although Sokhanvar (2008) believes that even Tennyson's bent about this poem rests on the "need of going forward and braving the struggle of life" after the death of Hallam his close and best friend (p. 814), it connotes to the king's sense of longing for the adventure that he did before and now though he is old, he has a try for it. It shows that he has enough sense to start his trips again to attack other countries, take over them and complement his own desires since it brings benefits to him and his own nation.

The poem also connotes to the hero of Homer's Odyssey and the medieval hero of Dante's Inferno. For Homer's Ulysses, it has been prophesized that he has only one another voyage after he kills his wife's suitors. However, the voyage is described by Dante in this way that Ulysses finds himself restless in Ithaca, and he wants to find other new places to both experience and loots the belongings. Dante's Ulysses (also like Marlow's Faustus) is a tragic hero who goes to hell while sailing too far in an insatiable thirst for knowledge. Tennyson expresses his love for these two accounts by making Ulysses have his final speech after he has returned to Ithaca and has taken his final decision to resume his administrative responsibilities before he decides to embark on his final voyage.

In the other lines of the poem, Tennyson tells us more about his sense for experiencing the world in order to confiscate and conquer even other distant places. He pursues his self-knowledge, the kind of knowledge which helps him know how to explore and takes other areas no matter how much they are far, provided that they provide him and his country the benefits they want. In order to fulfill his duty and extend his horizon on this matter, he needs to speak with his son, appoints him in his place and tells him about his embarking. He is now ready to go, but he needs his son to rule over the "rugged" people "This is my son... To whom I leave the scepter" (Tennyson, 2004, p. 426).

In order to start his voyage, the king needs to appoint his son, gives him his own place. His son also needs to subside his own people, and whenever force is needed; he must use it to suppress them. In other words, the king and his son must suppress their own people then the king can do his own business, "This labor, by slow prudence to make mild a rugged people" (Tennyson, 2004, p. 426). Solike Shelly's poem "England 1819" Tennyson implicitly shows his reader that kings have power and relegate their power to their sons as their heirs to rule over the meek people, to suppress them and make them obey, and it is here that imperialism blooms, it is not only in the host country but in its own. In contrast to Shelly's poem "England 1819" it is here in this poem that the king insults his people, calls them "savages race" (Tennyson, 2004, p. 426). His reason that he hates the people pinpoints on this account that the people don't want him to experience other places in order to loot other people's properties and make other people homeless; instead what they want is only peace and composure. Considering these two aspects, it is true that both poles (the king and his rabble) don't like each other, but unfortunately against the people's wish the authority is for him, the king has the right to rule his people and do not listen to them, he is all ears to his son and his son to him thus the imbalance of power is again demonstrated in the way that the kings have manipulated and controlled relationships between different groups of people who cannot mobilize to overthrow their power. Therefore, according to Foucault, "Power is not a commodity, a position, a prize, or a plot; it is the operation of the political technologies throughout the social body. The functioning of these political rituals of power is exactly what sets up the nonegalitarian, asymmetrical relations" (Dreyfus, 1983, p. 185).

In the final stanza he has prepared to go on his trip. He has called forth his peers, friends and all the crews that once they were together at sea and on land took and usurped a lot of placesthey had aimed for. He inspires them to attend in other trips to explore new lands and usurp the properties and belongings, he also reminds the mariners to risk with "free heart" and tastethe sweetness of their trips. Ulysses believes that they should not waste their time and though they are old now, they have the potency of their youth to go on more. His final speech to his friends is that "tis not late to seek a newer world" (Tennyson, 2004, p. 426), whenever they wish.

\section{Conclusion}

"Ulysses," likesome of his other poems, shows Tennyson's hidden conservative idea about the time that England tried to empowerits military defense. At that time England mostly paid attention to technological developments and didn't solve other problems that people and farmers had. These technological advances which triggered by advances in science led the bureaucrats of England to pass the law to attack, colonize and usurp the belongings of other countries. By viewing the poem from the imperialistic point of view, one can interpret that the king's sense of re-starting his voyage is to colonize other counties. This sense for the king to be a colonizer is shown when he wants to possess more marginal places in order to define self. But to a degree, it is not so easy for him since first he must condemn his people to make them obey his rules and second he can start his business. However, in one point the poem deals with the power of imperialism and shows that imperialism cannot stand still, but it must move outwards to the remote farther and farther away. 


\section{References}

Dreyfus, H. L., Rabinow, P., \& Foucault, M. (1983). Michel Foucault, beyond structuralism and hermeneutics. Chicago: University of Chicago Press.

Fletcher, R. H. (2005). A History of English Literature (10th ed.).

Grek-Martin, J. (2015). Key Concepts in Historical Geography. Journal of Historical Geography, 48, 73-75. https://doi.org/10.1016/j.jhg.2014.09.002

Hobson, J. A. (2009). Hobson's Imperialism, A study in Late-victorian Political Thought. Jyväskylä University.

McDowal, D. (1989). An Illustration History of Britain. Edinburgh, Britain: British Library.

Sokhanvar, J. (2008). An Abridged Edition of The Norton Anthology of English literature (1st ed., vol. 1). Tehran, Iran: Eshtiaghe Noor.

Tennyson, A. L. (2004). Classical Poetry Series. PoemHunter.com-The World-s Poetry Archive.

Tyson, L. (2006). Critical Theory Today: A User-Friendly Guide (2nd ed.). Hoboken: Routledge.

\section{Copyrights}

Copyright for this article is retained by the author(s), with first publication rights granted to the journal.

This is an open-access article distributed under the terms and conditions of the Creative Commons Attribution license (http://creativecommons.org/licenses/by/4.0/). 